\title{
PERANAN RUANG KOMUNAL DALAM MEWADAHI PERILAKU SOSIAL MASYARAKAT KAMPUNG RATMAKAN
}

\author{
Anggar Prasetyo \\ Program Magister Arsitektur, Universitas Atma Jaya Yogyakarta \\ anggar.pras01@gmail.com
}

Naskah diajukan pada: 23 Juli 2019

Naskah revisi akhir diterima pada: 12 November 2019

\begin{abstract}
Abstrak
Kampung Ratmakan merupakan sebuah kawasan perkampung yang terletak di tengah perkotaan Yogyakarta. Kampung Ratmakan memiliki citra yang bersih dan ikatan sosial yang kuat antar anggota masyarakat. Namun perilaku masyarakat perkotaan menjadi ancaman bagi masyarakat Kampung Ratmakan yang berada di tengah perkotaan. Ancaman datang berupa dari karakter masyarakat perkotaan yang cenderung individu dan bersebrangan dengan karakter sosial masyarakat kampung. Untuk itu dibangun beberapa ruang komunal pada Kampung Ratmakan yang terletak ditengah perkampungan dan tersebar ditepi Sungai Code sebagai langkah antisipatif dari ancaman karakter sosial masyarakat.. Ruang-ruang komunal tersebut dibangun untuk mewadahi aktifitas perilaku masyarakat dengan membentuk setting ruang pada tiap ruang komunal. Sehingga perlu diketahui sejauh mana ruang-ruang komunal tersebut dengan setting yang ada mampu mewadahi aktifitas komunal masyarakat Kampung Ratmakan. Metode dalam penelitian ini adalah metode kualitatif dengan pencarian data menggunakan teknik observasi langsung dan wawancara mendalam. Kemudian dari data-data tersebut dikaitkan dengan teori-teori mengenai konsep affordance dan karakter masyarakat kampung. Hasil yang dicapai menyatakan bahwa ruang komunal tepi sungai dan ruang komunal tengah kampung memiliki peranan berbeda untuk mewadahi perilaku sosial masyarakat. Ruang komunal tengah kampung cenderung berperan sebagai physical affordances melalui fasilitas-fasilitas yang ada. Sedangkan ruang komunal tepi sungai cenderung berperan sebagai sensory affordances melalui kenyamanan thermal yang terbentuk.
\end{abstract}

Kata-kata Kunci: affordance, kampung, ruang komunal

\section{ROLE OF COMMUNAL SPACES IN ACCOMMODATING SOCIAL COMMUNITY BEHAVIOR OF RATMAKAN KAMPUNG}

\begin{abstract}
Kampung Ratmakan is an area that located in the middle part of Yogyakarta. Kampung Ratmakan has character as clean kampong and they have strong social relation between member of kampong. But the character of urban citizen has became threat for Ratmakan people. The threat has the shape of urban citizen character that inclined as individuality and become threat for kampong people character. So, they had built several communal spaces in the Kampung Ratmakan that located in the middle part of kampong and the side of Code River. The communal spaces are built to accommodate the behavior of the community by forming a space setting in each communal space. So that it is necessary to know the extent to which communal spaces have been contested with the existing settings capable of accommodating communal activities of the Kampung Ratmakan
\end{abstract}


community. The method in this study is a qualitative method with data search using direct observation techniques and in-depth interviews. Then from these data are associated with theories about the concept of affordance and character of the village community. The results achieved stated that the riverside communal space and the middle communal space of the village had different roles to accommodate the social behavior of the community. Central village communal space tends to act as physical affordances through existing facilities. While riverfront communal spaces tend to act as sensory affordances through the thermal comfort that was formed.

Keywords: affordance, kampong, communal space

\section{Pendahuluan}

Kampung Ratmakan terletak di Kelurahan Ngupasan, Kecamatan Gondokusuman, Yogyakarta dan merupakan salah satu kampung yang ada pada bantaran Kali Code. Secara demografis, kampung ratmakan memiliki penduduk berjumlah 1083 jiwa dengan komposisi 536 jiwa penduduk laki-laki dan 547 jiwa penduduk perempuan. Keseluruhan penduduk tersebar di tiga RW yang meliputi RW 007, RW 008, dan RW009. Kecenderungan pemukiman pada tepian Kali Code terkenal dengan pemukiman kumuh dan kotor. Namun kecenderungan tersebut tidak berlaku pada Kampung Ratmakan. Pada Kampung Ratmakan, suasana yang tercipta merupakan suasana yang bersih dan tidak kumuh. Situasi tersebut tercipta dari kuatnya ikatan sosial yang terjalin dalam masyarakat. Keberadaan kampung yang berada pada tengah perkotaan, menyebabkan sifat individualis kaum perkotaan menjadi ancaman bagi kekerabatan sosial yang ada pada Kampung Ratmakan. Untuk menghindari ancaman tersebut, maka pada Kampung Ratmakan membentuk beberapa ruang-ruang komunal yang muncul ditengah masyarakat. Ruang-ruang komunal tersebut tercipta untuk mempertahankan ikatan sosial yang ada pada Kampung Ratmakan.

Ruang komunal memiliki peranan penting dalam mewadahi perilaku sosial masyarakat. Ruang komunal adalah ruang yang mampu menampung kegiatan sosial dan digunakan oleh seluruh masyarakat (Purwanto \& Wijayanti, 2009). Ruang komunal juga memberi kesempatan bagi masyarakat untuk saling bertemu. Namun untuk saling betemu antar anggota masyarakat, maka diperlukan katalisator (Lang, 1987). Pada Kampung Ratmakan, keberadaan katalisator berada menjadi satu dengan setting ruang yang ada. Setting ruang memuat katalisator yang mengakibatkan setiap individu saling bertemu. Akibatnya terjadi perilaku sosial yang diwadahi pada ruang komunal Kampung Ratmakan. Dengan demikian keberadaan ruang komunal peranannya sangat diperlukan oleh masyarakat Kampung Ratmakan.

Dari uraian tersebut maka dapat dinyatakan bahwa ruang-ruang komunal di Kampung Ratmakan memiliki peranannya masing-masing dalam mewadahi aktifitas komunal. Peranan tersebut diaplikasikan dalam setiap setting tipe ruang komunal. Sehingga perlu diketahui peranan dari setiap tipe ruang komunal berdasarkan setting yang ada dalam mewadahi aktfitas perilaku sosial masyarakat.

\section{Kajian Teori \\ Konsep Affordance}

Setting pada sebuah lingkungan memiliki konsep affordance tersendiri bagi pengguna. Menurut (Gibson, 1979) affordance merupakan atribut dari desain interaksi yang ditawarkan ke pengguna. Selanjutnya Gibson menjelaskan sifat-sifat yang mendasari sebuah affordance antara lain:

1. Tingkat pencapaian affordance sebuah setting tergantung kepada kemampuan orang yang menggunakannya.

2. Keberadaan affordance sebuah setting tergantung pada bagaimana cara orang tersebut 
3. Affordance sebuah perangkat tidak akan berubah sesuai dengan perubahan kebutuhan dan tujuan dari pengguna.

Dalam pengklasifikasinya, affordance dibagi menjdi empat jenis (Hartson, 2003). Jenis affordance tersebut dibagi berdasarkan bagainana sebuah setting mewadahi sebuah perilaku. Keempat setting tersebut antara lain adalah sebagai berikut.

1. Cognitive Affordances

Merupakan sebuah fitur desain yang digunakan untuk membantu, menolong, memfasilitasi dan mendukung atau membuka pikiran atau pengetahuan tentang sesuatu. Contohnya adalah sebuah rambu-rambu pada publik space.

2. Physical Affordances

Merupakan sebuah fitur desain yang digunakan untuk membantu, menolong, memfasilitasi dan mendukung atau tersedia secara fisik untuk melakukan sesuatu. Salah satu contohnya adalah bangku pada taman yan digunakan sebagai tempat beristirahat.

3. Sensory Affordances

Merupakan sebuah konsep tambahan. Sensory Affordances diartikan sebagai sebuah fitur desain yang digunakan untuk membantu, menolong, memfasilitasi dan mendukung atau disediakan bagi pengguna untuk merasakan (sensing). Sensing dapat dilakukan melalui pendengaran (suara), melihat (cahaya) dan meraba (tekstur dan suhu). Salah satu contohnya adalah pengaturan pencahayaan pada ruangan untuk menciptakan nuansa visual tertentu.

4. Funcional Affordances

Merupakan desain fitur yang membantu pengguna dalam menyelesaikan pekerjaan. Fitur ini dapat dilihat dari kegunaan dan fungsi sebuah sistem. Contohnya adalah penggunaan software dalam menciptakan desain arsitektur.

\section{Karakter Perilaku Masyarakat Kampung}

Kampung yang berada pada tengah perkotaan atau kampung kota memiliki persamaan karakter dengan masyarakat pedesaan. Hal ini dijelaskan dalam teori Talcott Parsons yang menyatakan karakter dari masyarakat kampung yang ada di tengah perkotaan antara lain adalah sebagai berikut.

Tabel 1. Perilaku Sosial Masyarakat Kampung

Perilaku Penjelasan

Setiap individu memiliki perasaan saling saying dan peduli satu sama lain. Hal ini kemudian berdampak terhadap sikap dan budaya saling tolong menolong, bersimpati pada musibah yang diderita tetangga, dan menolong tanpa pamrih.

$\begin{array}{ll}\text { Orientasi } & \text { Mendahulukan kebersamaan, mereka kurang suka menonjolkan diri, banyak } \\ \text { kolektif } & \text { yang tidak suka konfik (perbedaan pendapat), semua orang memperlihatkan } \\ & \text { keseragaman dalam persamaan. }\end{array}$

Parkiluarisme Lebih menunjukan sifat sangat subyektif, kebersamaan yang mementingkan kelompok mereka sendiri jika ada serangan dari luar.

Askripsi

Kekabaran
Adat atau budaya yang sudah menjadi kebiasaan secara turun temurun terus dijaga.

Untuk menjaga harmoni, kebanyakan masyarakat kampung menggunakan komunikasi bahasa tidak langsung. Baik ketika menunjukkan sesuatu, mengingatkan dan menegur. 


\section{Metode}

Penelitian ini menggunakan metode kualitatif dengan melihat fenomena-fenomena perilaku sosial masyarakat Kampung Ratmakan dan dikaitkan dengan setting ruang komunal yang tersedia. Tahap awal dari metode penelitian ini adalah melakukan pengambilan data. Pengambilan data dalam penelitian menggunakan metode observasi langsung pada ruang-ruang komunal untuk mengamati perilaku masyarakat dalam menggukan ruang-ruang komunal serta keadaan fisik dari ruang-ruang komunal di Kampung Ratmakan di Kampung Ratmakan. Selain penelitian juga menggunakan metode wawancara yang mendalam terhadap masyarakat sekitar pengguna ruang komunal di Kampung Ratmakan. Setelah melakukan pengambilan data, maka dilakukan analisis terhadap datadata tersebut. Metode analisis yang digunakan pada penelitian ini adalah mengkomparasikan dan mengkatagorikan data-data lapangan yang telah diperoleh mengenai ruang komunal di Kampung Ratmakan dengan teori-teori affordance yang ditemukan. Kemudian dari analisis dijabarkan mengenai perilaku apa saja yang terbentuk dari keberadaan ruang komunal tersebut.

\section{Temuan dan Pembahasan}

\section{Karakter Masyarakat Kampung Ratmakan}

Kampung Ratmakan berada ditengah Kota Yogyakarta sehingga masyarakat Kampung Ratmakan memiliki karakter seperti yang disebutkan oleh Talcott. Karakter-karakter tersebut dijabarkan dalam aktifitas komunal warga kampung. Berikut merupakan penjabaran perilaku aktivitas sosial dari setiap karakter masyarakat kampung.

Tabel 2. Perilaku Sosial Masyarakat Kampung Ratmakan

\begin{tabular}{lcl}
\hline Karakter & Perilaku Aktivitas Sosial \\
\hline Afektifitas & - & Kebiasaan rewang yang terjalin hingga sekarang \\
& - & Solidaritas masyarakat antar tetangga ketika diadakannya hajat dari salah \\
Orientasi & seorang warga \\
kolektif & - & Kerja bakti yang rutin dilakukan untuk menjaga kebersihan kampung \\
\hline Partikularisme & - & Sarana kebutuhan masyarakat sehari-hari untuk menjemur nasi \\
\hline Askripsi & - & $\begin{array}{l}\text { Munculnya berbagai organisasi dalam kampung untuk mendukung } \\
\text { aktifitas sosial dalam kampung }\end{array}$ \\
\hline Kekabaran & - & $\begin{array}{l}\text { Munculnya beberapa festival dalam kampung yang diselenggarakan } \\
\text { secara rutin }\end{array}$ \\
\hline
\end{tabular}
Sumber: Analisis Penulis, 2019

\section{Ruang komunal Kampung Ratmakan}

Pada Kampung Ratmakan terdapat dua jenis ruang komunal. Ruang komunal tersebut dibedakan berdasarkan peletakannya. Ruang komunal terdiri atas ruang komunal tepi sungai dan ruang komunal ditengah kampung.

\section{Ruang Komunal Tepi Sungai}

Ruang komunal yang berada ditepi sungai digunakan oleh masyarakat untuk saling bertemu satu sama lain. Secara fisik, ruang komunal ditepi sungai berwujud dengan bangunan dengan pelingkup diatasnya tanpa dinding penutup pada sisi-sisi sampingnya. Secara material, ruang komunal ditepi Sungai Code dipasang dengan perkerasan ubin keramik. 


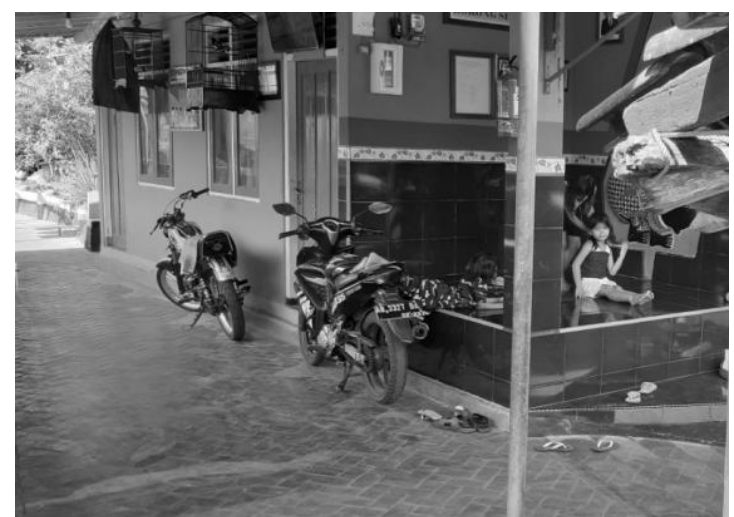

Gambar 1. Ruang Komunal Tepi Sungai

Sumber: Dokumentasi Penulis, 2019

Ruang komunal tepi sungai menjalankan peranan sebagai area berkumpul setiap saat hingga ketika terdapat acara dari penduduk. Area komunal tepi sungai cenderung digunakan oleh masyarakat untuk tempat bertemu dan saling mengobrol satu sama lain. Berikut aktifitas yang terjadi pada ruang komunal tepi sungai.

Tabel 3. Aktivitas Komunal Ruang Tepi Sungai

\begin{tabular}{cccc}
\hline Pagi & \multicolumn{1}{c}{ Siang } & Sore/malam \\
\hline- & Anak-anak & - & Mengobrol \\
bermain & - & Tidur & Mengobrol \\
\hline
\end{tabular}

Sumber: Analisis Penulis, 2019

Aktifitas yang dilakukan masyarakat pada ruang komunal tepi sungai dipicu oleh suhu udara yang panas didalam hunian masyarakat. Sehingga masyarakat banyak menghabiskan waktu pada area komunal tepi sungai untuk mendapatkan kenyamanan thermal yang diinginkan.

\section{Ruang Komunal Tengah Kampung}

Untuk menunjang aktifitas warga dengan jumlah besar, maka dimunculkan sebuah ruang kmunal yang terletak di tengah kampung. Ruang komunal berada ditengah kampung agar mudah diakses masyarakat kampung. Selain itu ruang komunal tegah kampung juga difungsikan sebagai sentral kampung.

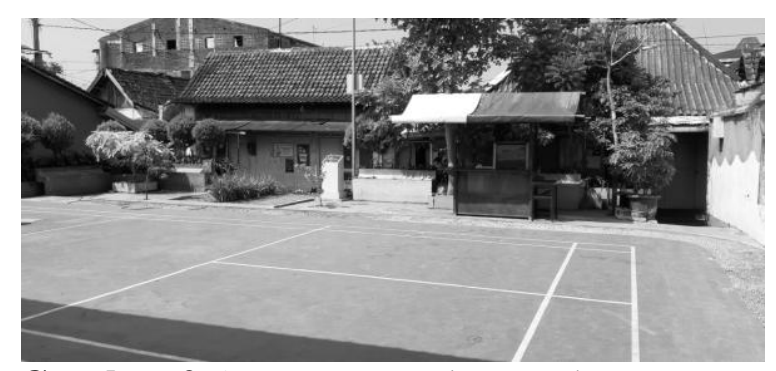

Gambar 2 Area Komunal Tengah Kampung

Sumber: Dokumentasi Penulis, 2019

Ruang komunal yang berada ditengah kampung cenderung memiliki kuantitas daya tampung lebih besar. Ruang komunal berwujud area olah raga yang dilengkapi dengan fasilitas-fasilitas pendukung seperti panggung, televisi dan angkringan. Elemen pendukung yang ada pada ruang komunal kampung tersberfungsi sebagai media masyarakat berkumpul dan diorientasikan pada panggung. 


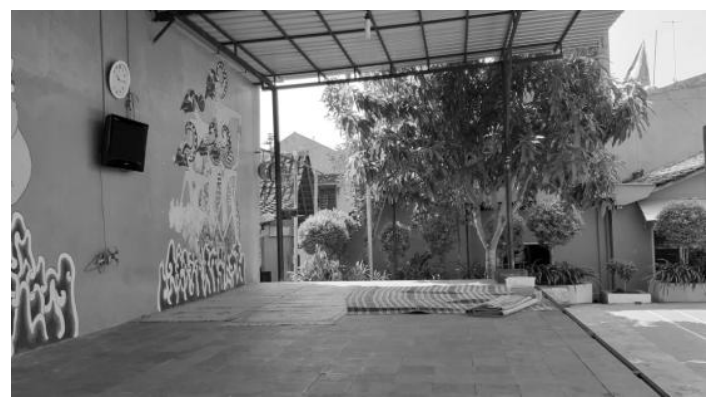

Gambar 3 Panggung Pada Area Komunal Tengah Kampung Sumber: Dokumentasi Penulis, 2019

Panggung pada area komunal tengah kampung difungsikan sebagai fokus aktifitas masyarakat dalam acara sekala besar. Dalam memfasilitasi aktifitas komunal keseharian warganya, panggung dilengkapi dengan televisi. Televisi difungsikan sebagai salah satu daya tarik ruang komunal.

\section{Peranan Ruang Komunal Pada Kampung Ratmakan}

Ruang komunal pada Kampung Ratmakan memiliki katalisator pada settingnya untuk memacu orang saling berkumpul satu sama lain. Katalisator pada setting berkaitan mengenai bagaimana setiap individu memanfaatkan ruang untuk kebutuhan sosial dan persamaan kebutuhan pribadi yang dilakukan secara bersama dan menimbulkan aktifitas komunal. Berikut merupakan aktifitas yang ditampung pada masing-masing ruang komunal berdassarkan perilaku masyarakat kampung,

Tabel 4. Kategorisasi Perilaku Masyarakat Kampung Ratmakan

\begin{tabular}{lll}
\hline Jenis Ruang Komunal & \multicolumn{1}{c}{ Aaktivitas yang terjadi } & Kategori Perilaku \\
\hline \multirow{2}{*}{$\begin{array}{l}\text { Ruang komunal tepi } \\
\text { sungai }\end{array}$} & $-\begin{array}{l}\text { Digunakan sebagai area rewang masyarakat } \\
\text { yang berbatasan dengan Sungai Code }\end{array}$ & Afektivitas \\
\cline { 2 - 3 } & $-\begin{array}{l}\text { Aktifitas mengobrol antar tetangga yang } \\
\text { timbul secara spontan }\end{array}$ & Pengkabaran \\
\hline & $-\begin{array}{l}\text { Digunakan ketika salah seorang masyarakat } \\
\text { memiliki hajat dan dibantu warga lainya. }\end{array}$ & Afektivitas \\
\cline { 2 - 3 } $\begin{array}{l}\text { Ruang komunal } \\
\text { tengah kampung }\end{array}$ & $\begin{array}{l}\text { Digunakan masyarakat sehari-hari untuk } \\
\text { secara bersama menjemur nasi }\end{array}$ & Orientasi Kolektif \\
& - Pusat kegiatan kerja bakti rutin & Orientasi kolektif \\
\hline & $-\begin{array}{l}\text { Pusat kegiatan organisasi masyarakat } \\
\text { Kampung Ratmakan }\end{array}$ & Partikularisme \\
\cline { 2 - 3 } & $-\begin{array}{l}\text { Digunakan sebagai area event rutin Kampung } \\
\text { Ratmakan }\end{array}$ & Askripsi \\
\hline
\end{tabular}

Sumber: Analisis Penulis, 2019

Setting ruang komunal pada tepi sungai memiliki beberapa katalisator pendukung dimana masyarakat dapat berkumpul dan menjalankan asktifitas perilaku sosial berdasarkan krakter masyarakat kampung. Pada setiap jenis ruang komunal memiliki setting yang berbeda dan memiliki perbedaan jenis aktivitas yang diwadahi. Berikut merupakan identifikasi konsep affordance pada ruang komunal tepi sungai dan klasifikasinya. 
Tabel 5. Klasifikasi Affordance Ruang Komunal Tepi Sungai Kampung Ratmakan

\begin{tabular}{|c|c|c|c|}
\hline Aktivitas sosial & Konsep affordance & Katalisator & $\begin{array}{l}\text { Klasifikasi } \\
\text { affordance }\end{array}$ \\
\hline $\begin{array}{l}\text { Digunakan } \\
\text { sebagai area } \\
\text { rewang } \\
\text { masyarakat yang } \\
\text { berbatasan } \\
\text { dengan Sungai } \\
\text { Code }\end{array}$ & $\begin{array}{l}\text { - Ruang komunal bersifat } \\
\text { terbuka, dan berada pada titik- } \\
\text { titik merata disepanjang Kali } \\
\text { Code memungkinkan } \\
\text { masyarakat untuk mudah } \\
\text { mengakses dan memiliki } \\
\text { tempat duduk permanen }\end{array}$ & $\begin{array}{ll}\text { - } & \text { Bentuk ruang } \\
\text { terbuka } \\
\text { - } & \text { Tempat duduk } \\
\text { permanen }\end{array}$ & $\begin{array}{l}\text { Physical } \\
\text { Affordances }\end{array}$ \\
\hline $\begin{array}{l}\text { Aktifitas } \\
\text { mengobrol antar } \\
\text { tetangga yang } \\
\text { timbul secara } \\
\text { spontan }\end{array}$ & $\begin{array}{l}\text { - Ruang berpelingkup tanpa } \\
\text { pembatas pada sisi-sisi } \\
\text { samping area komunal dan } \\
\text { berada pada tepi sungai. } \\
\text { Memugkinkan suhu yang lebih } \\
\text { rendah dan sejuk daripada } \\
\text { suhu hunian masyarakat } \\
\text { - Penggunaan material keramik } \\
\text { menjadikan ruang memiliki } \\
\text { kesan lebih dingin. }\end{array}$ & $\begin{array}{ll}\text { - } & \text { Bentuk ruang } \\
\text { terbuka } \\
\text { - } & \text { Penggunaan } \\
\text { material } \\
\text { keramik } \\
\text { - } & \text { Sungai }\end{array}$ & $\begin{array}{l}\text { Sensory } \\
\text { Affordances }\end{array}$ \\
\hline
\end{tabular}

\section{Sumber: Analisis Penulis, 2019}

Dalam keseharian rutin juga terjadi aktifitas komunal pada ruang komunal tepi sungai. Aktifitas rutin yang dilakukan masyarakat pada kesehariannya dilakukan masyarakat secara bersama antar anggota masyarakat. Aktifitas komunal yang rutin pada tepi sungai mencakup hal-hal berikut.

Tabel 6. Kategorisasi Affordance Pada Ruang Komunal Tepi Sungai Pada Lingkup Sehari-Hari

\begin{tabular}{lllll}
\hline Waktu & Aktivitas & Katalisator & Kategori \\
\hline Pagi & & & \\
\end{tabular}




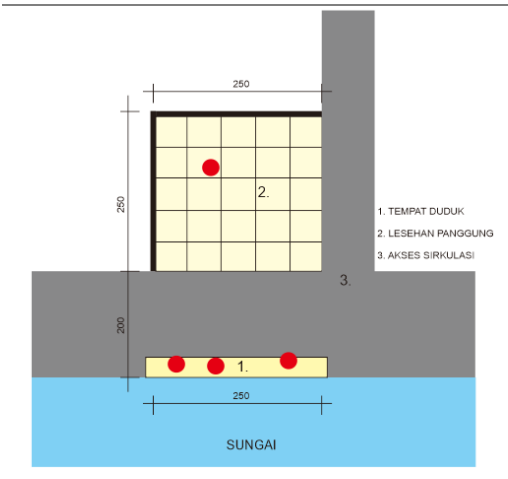

Pemetaan Siang

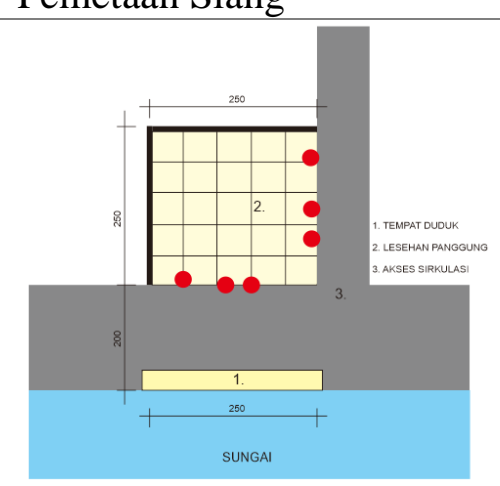

Pemetaan sore/malam
- Digunakan

tidur akibat

nuansa sejuk

pada ruang

komunal

- Digunakan

mengobrol

pada bangku

area komunal $\begin{array}{ll}\text { - Nuansa sejuk } & \begin{array}{l}\text { Sensory } \\ \text { Affordances }\end{array}\end{array}$
- Digunakan mengobrol pada area panggung
- Nuansa sejuk
Sensory

Affordances

Sumber: Analisis Penulis, 2019

Pada area komunal tepi Sungai Code klasifikasi affordance cenderung berada dalam kategori sensory affordance. Kecenderungan dilakukan masyarakat untuk mencapai kenyamanan thermal bagi masyarakat. Keberadaan nuansa sejuk dengan setting ruang terbuka ditepi sungai menjadi katalisator masyarakat berkumpul. Berbeda dengan ruang komunal tepi sungai, keberadaan ruang komunal di tengah kampung memiliki katalisator yang lebih banyak. Dengan katalisator pada setting yang lebih banyak menimbulkan keberagaman aktivitas yang tejadi. Berikut merupakan identifikasi konsep affordace pada ruang komunal tengah kampung dan klasifikasinya.

Tabel 7. Klasifikasi Affordance Pada Ruang Komunal Tengah Kampung

\begin{tabular}{|c|c|c|c|}
\hline Aktivitas sosial & Konsep affordance & Katalisator & $\begin{array}{l}\text { Klasifikasi } \\
\text { affordance }\end{array}$ \\
\hline $\begin{array}{l}\text { Digunakan ketika salah } \\
\text { seorang masyarakat } \\
\text { memiliki hajat dan } \\
\text { dibantu warga lainya. }\end{array}$ & $\begin{array}{l}\text { - Keberadaan panggung sebagai } \\
\text { vocal point dan ruang komunal } \\
\text { yang luas memungkinkan untuk } \\
\text { menampung masyarakat dalam } \\
\text { jumlah banyak. }\end{array}$ & $\begin{array}{ll}- & \text { Panggung } \\
\text { - } & \text { Area luas }\end{array}$ & $\begin{array}{l}\text { Physical } \\
\text { Affordances }\end{array}$ \\
\hline $\begin{array}{l}\text { Digunakan masyarakat } \\
\text { sehari-hari untuk } \\
\text { secara bersama } \\
\text { menjemur nasi }\end{array}$ & $\begin{array}{l}\text { - Area yang panas dan luas } \\
\text { memungkinan masyarakat secara } \\
\text { bersama menjemur nasi yang } \\
\text { menimbulkan aktivitas komunal }\end{array}$ & $\begin{array}{ll}- & \text { Area luas } \\
- & \text { Panas } \\
& \text { matahari }\end{array}$ & $\begin{array}{l}\text { Physical } \\
\text { Affordances }\end{array}$ \\
\hline $\begin{array}{l}\text { Pusat kegiatan kerja } \\
\text { bakti rutin }\end{array}$ & $\begin{array}{l}\text { - Area berbentuk terbuka, mudah } \\
\text { diakses dan terletak ditengah } \\
\text { kampung menjadikan area mudah } \\
\text { dikenali oleh masyarakat untuk } \\
\text { menjadi patokan area berkumpul }\end{array}$ & $\begin{array}{ll}\text { - } & \text { Area luas } \\
\text { - } & \text { Area } \\
& \text { terbuka }\end{array}$ & $\begin{array}{l}\text { Physical } \\
\text { Affordances }\end{array}$ \\
\hline Pusat kegiatan & - Keberadaan area komunal yang & Area luas & Physical \\
\hline
\end{tabular}




\begin{tabular}{llll}
\hline $\begin{array}{l}\text { organisasi masyarakat } \\
\text { Kampung Ratmakan }\end{array}$ & $\begin{array}{l}\text { luas mampu menampung aktifitas } \\
\text { dalam jumlah banyak }\end{array}$ & Affordances \\
\hline $\begin{array}{l}\text { Digunakan sebagai } \\
\text { area event rutin } \\
\text { Kampung Ratmakan }\end{array}$ & $\begin{array}{l}\text { - Keberadaan area komunal yang } \\
\text { luas mampu menampung banyak } \\
\text { orang dalam aktifitas tertentu }\end{array}$ & - Area luas & $\begin{array}{l}\text { Physical } \\
\text { Affordances }\end{array}$ \\
\hline
\end{tabular}

Sumber: Analisis Penulis, 2019

Dalam keseharian rutin juga terjadi aktifitas komunal pada area komunal tengah kampung. Aktifitas komunal tengah kampung cenderung memanfaatkan fasilitas dan ukuran ruang pada area komunal tengah kampung. Aktifitas tersebut antara lain adalah sebagai berikut.

Tabel 8. Kategorisasi Affordance Pada Ruang Komunal Tepi Sungai Dalam Lingkup Sehari-Hari

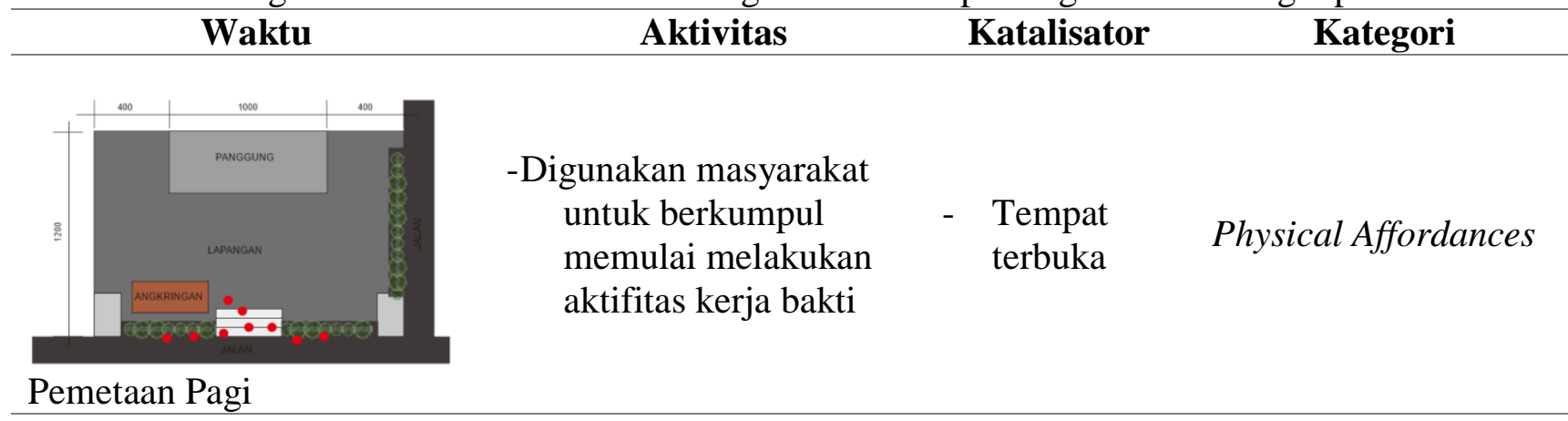

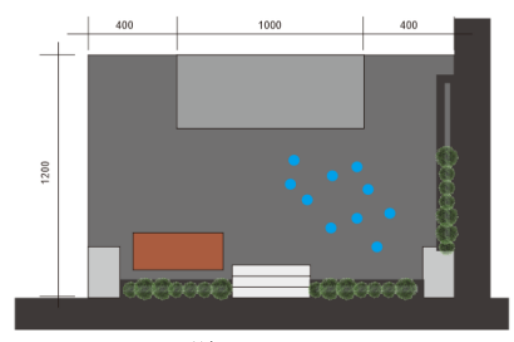

- Digunakan masyarakat untuk menjemur nasi kering

- Panas matahari Physical Affordances

- Area luas

Pemetaan Siang

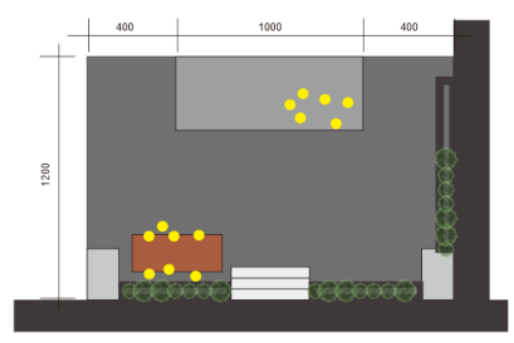

Pemetaan malam
- Digunakan masyarakat menonton televisi secara bersama pada bagian atas panggung

- Digunakan masyarakat Nuansa sejuk Physical Affordances untuk saling mengobrol pada lokasi anggringan

Sumber: Analisis Penulis, 2019

Pada area komunal tepi Sungai Code klasifikasi affordance cenderung berada dalam kategori physical affordances. Kecenderungan dilakukan masyarakat dengan memanfaatkan fasilitas-fasilitas yang ada pada ruang komunal ditengah kampung. Sehingga segala aktifitas komunal yang membutuhkan fasilitas dan daya tamping dalam jumlah besar cendrung banyak menggunakan area komunal tengah kampung. 


\section{Kesimpulan}

Dari penelitian ini didapatkan kesimpulan bahwa tipe ruang komunal di Kampung Ratmakan memiliki perbedaan dalam mewadahi aktifitas komunal masyarakat. Perbedaan didasarkan pada katalisator masing-masing setting ruang komunal. Ruang komunal yang tersebar tepi sungai yang memiliki katalisator nuansa sejuk pada tiap areanya menyebabkan masyarakat berkumpul untuk mencapai kenyamanan thermal sehingga dikategorikan dalam sensory affordances. Ruang komunal yang berada tengah kampung cenderung digunakan masyarakat dalam jumlah besar untuk memfasilitasi masarakat melakukan aktivitas komunal dengan katalisator wujud ruang komunal yang luas, fasilitas dan terik matahari sehingga dikategorikan dalam physical affordances.

\section{Daftar Pustaka}

Gibson, J. (1979). The Ecological Approach to Visual. Boston: Houghton Mifflin Co.

Hartson, H. (2003). Cognitive, physical, sensory, and functional affordances in interaction design. Behaviour \& Information Technology, 315-338.

Lang, J. (1987). Creating Architectural Theory. New York: Van Nostrand Reinhold Company.
Purwanto, E., \& Wijayanti. (2009). Pola Ruang Komunal di Rumah Susun Bandarharjo. Journal of Architecture and Built Environment, 23-30.

Ritzer, G., \& D.J. Goodman. (2004). Sociological Theory. New York: McGraw-Hill. 